\title{
Role of the adaptive immune response in sepsis
}

\author{
Jack Brady ${ }^{1,2 \dagger}$, Shahd Horie ${ }^{1,2+}$ and John G. Laffey ${ }^{1,2,3^{*}}$ (i)
}

From 4th International Symposium on Acute Pulmonary Injury and Translational Research - INSPIRES 2019

Dresden, Germany. 25-26 November 2019

\author{
* Correspondence: john.laffey@ \\ nuigalway.ie \\ † Jack Brady and Shahd Horie \\ contributed equally to this work. \\ ${ }^{1}$ Anaesthesia, School of Medicine, \\ Clinical Sciences Institute, National \\ University of Ireland, Galway, Ireland \\ ${ }^{2}$ Regenerative Medicine Institute \\ (REMEDI) at CÚRAM Centre for \\ Research in Medical Devices, \\ Biomedical Sciences Building, \\ National University of Ireland \\ Galway, Galway, Ireland \\ Full list of author information is \\ available at the end of the article
}

\begin{abstract}
Sepsis is a syndrome of shock and dysfunction of multiple vital organs that is caused by an uncontrolled immune response to infection and has a high mortality rate. There are no therapies for sepsis, and it has become a global cause for concern. Advances in patient care and management now mean that most patients survive the initial hyper-inflammatory phase of sepsis but progress to a later immunosuppressed phase, where $30 \%$ of patients die due to secondary infection. Deficits in the adaptive immune response may play a major role in sepsis patient mortality. The adaptive immune response involves a number of cell types including T cells, B cells and dendritic cells, all with immunoregulatory roles aimed at limiting damage and returning immune homeostasis after infection or insult. However, in sepsis, adaptive immune cells experience cell death or exhaustion, meaning that they have defective effector and memory responses ultimately resulting in an ineffective or suppressed immune defence. CD4+ T cells seem to be the most susceptible to cell death during sepsis and have ensuing defective secretory profiles and functions. Regulatory $T$ cells seem to evade apoptosis and contribute to the immune suppression observed with sepsis. Preclinical studies have identified a number of new targets for therapy in sepsis including anti-apoptotic agents and monoclonal antibodies aimed at reducing cell death, exhaustion and maintaining/restoring adaptive immune cell functions. While early phase clinical trials have demonstrated safety and encouraging signals for biologic effect, larger scale clinical trial testing is required to determine whether these strategies will prove effective in improving outcomes from sepsis.
\end{abstract}

Keywords: Sepsis, Immune suppression, Immune homeostasis

\section{Background}

Sepsis is a clinical syndrome defined as 'life-threatening organ dysfunction caused by a dysregulated host immune response to infection' [1]. Sepsis is a major health concern and a leading contributor to mortality and critical illness globally [2, 3]. In 2011, it was responsible for more than $\$ 20$ billion in expenses in all US hospitals [4]. In 2017, global sepsis incidence was estimated at 48.9 million cases and sepsis-associated deaths were estimated at 11.0 million cases [3]. The highest incidence has been observed in

(c) The Author(s). 2020 Open Access This article is licensed under a Creative Commons Attribution 4.0 International License, which permits use, sharing, adaptation, distribution and reproduction in any medium or format, as long as you give appropriate credit to the original author(s) and the source, provide a link to the Creative Commons licence, and indicate if changes were made. The images or other third party material in this article are included in the article's Creative Commons licence, unless indicated otherwise in a credit line to the material. If material is not included in the article's Creative Commons licence and your intended use is not permitted by statutory regulation or exceeds the permitted use, you will need to obtain permission directly from the copyright holder. To view a copy of this licence, visit http://creativecommons.org/licenses/by/4.0/. 
young children and the elderly, with the main causes being lower respiratory tract and abdominal infections [3]. The incidence of sepsis is also expected to rise as a result of an ageing population that has numerous comorbidities and an increasingly impaired immune system [3, 5, 6]. Multi-drug-resistant bacterial pathogens are another major challenge meaning that sepsis is becoming increasingly difficult to manage clinically. Patients who survive sepsis are often seen to possess long-term complications including physical, psychological and cognitive impairments with additional negative healthcare and social implications [7].

Septic patients frequently present with fevers, cardiovascular shock and respiratory and/or systemic organ failure [8]. The prototypical clinical features of early sepsis result primarily (but not always) from an overwhelming, 'pro-inflammatory' immune response which has led to many drug trials attempting to block these pro-inflammatory effects [9]. However, strategies attempting to dampen this overactive immune response to infection, by blocking interleukin (IL)- $1 \beta$ and tumour necrosis factor (TNF)- $\alpha$ for example, ultimately failed in producing any survival benefit [10]. Over 100 clinical trials with different pharmacological agents have taken place, yet no single FDA-approved therapeutic agent exists that is capable of improving survival in patients with sepsis [11]. Clinical outcomes of patients from the initial hyper-inflammatory phase have improved over the last decade with aggressive source control, earlier appropriate antibiotic therapy, titrated fluid and pressor therapy, and better organ supportive measures, particularly ventilator management [12].

Unfortunately, despite these improvements, and despite the fact that more people are now surviving the initial stages of septic shock and organ dysfunction, sepsis remains responsible for the most deaths in intensive care units (ICU's) [12] and long-term mortality is still in the region of $40-80 \%$ [13]. This is because patients are now more frequently transitioning into a later state of prolonged immune suppression [14] (Fig. 1).

Impairments in the adaptive immune response increase the likelihood of developing persistent, recurring, secondary and nosocomial infections which often lead to death in sepsis patients [16]. With increasing numbers of patients developing these immune complications, more recent research efforts are now focussing on attempting to understand the underlying changes that occur to both innate and adaptive immune cell populations and highlighting potential new targets for therapy for this syndrome. In this review, we will focus solely on the effects that sepsis has on the adaptive immune system. We will then focus on how some of the immune cells involved in adaptive immunity may be directly targeted to provide potential therapeutic benefit in treating this syndrome and improving long-term survival.

\section{The innate versus the adaptive immune response}

There are two components of the human immune system, and these are the innate and adaptive immune systems. The innate immune system is the first line of defence against invading pathogens and acts rapidly and non-specifically to fight infection. The adaptive immune system, in contrast, is much slower to respond, but is capable of recognising unique antigens and utilising immunological memory to enhance the immune response following subsequent exposures of the same antigens. Both components of the immune system comprise of a variety of cell types. In the innate system, there are natural killer (NK) cells, mast cells, eosinophils, basophils and phagocytic cells which 


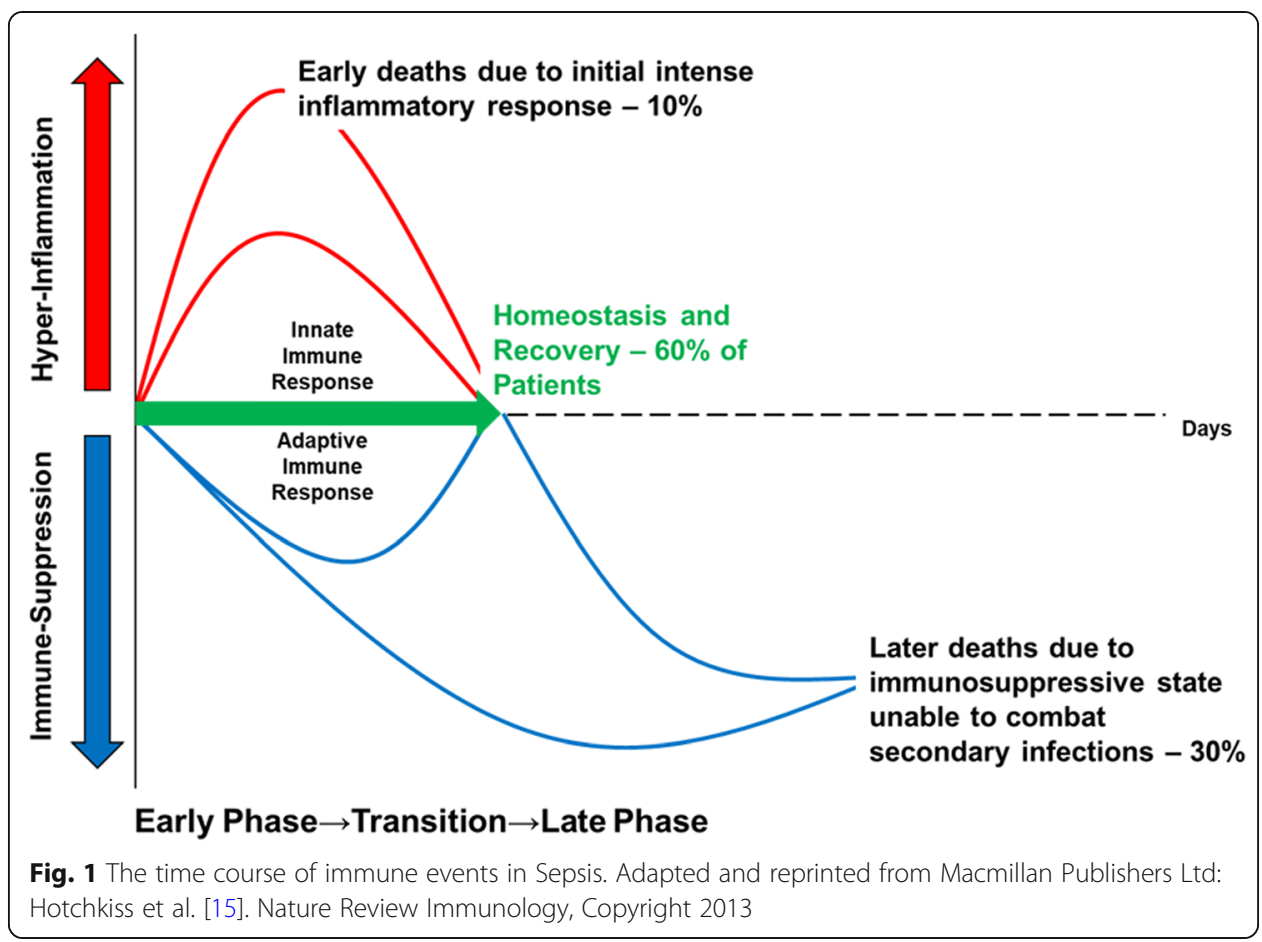

include macrophages, dendritic cells (DCs) and neutrophils. The adaptive immune system relies on fewer cell types to carry out its operations, and these are lymphocytes, namely $\mathrm{T}$ cells and $\mathrm{B}$ cells. $\mathrm{B}$ cells are known to be important producers of antibodies and plasma cells necessary for long-term immune protection, while $\mathrm{T}$ cells can be classified further into a number of different subclasses, each with unique functions, and these include $\mathrm{CD} 4+, \mathrm{CD} 8+$, gamma delta $(\gamma \delta)$ and regulatory T cells (Tregs) (Fig. 2).

\section{Adaptive immune cell functions}

CD4+ $\mathrm{T}$ cell activation results in rapid polarisation into $\mathrm{CD} 4+$ subsets which are $\mathrm{T}$ helper (Th) 1, Th2 or Th17. The Th1 class is important for the activation of CD8+ T cells and for the formation of memory T cells via IL-2 secretion $[17,18]$. Th2 cells are involved in class switching of B lymphocytes via IL-4 and IL-5 secretions [19], and Th17 cells are effector cells that produce IL-17, IL-22 and TNF- $\alpha$ primarily in response to extracellular fungal and bacterial pathogens [20]. In addition, CD8+ T cells are responsible for the clearing of an infection and for the generation of memory CD8+ T cells in response to infection or vaccination [21]. Once CD8+ T cells bind their cognate antigen in the presence of co-stimulatory molecules and cytokines, they undergo rapid proliferation and expand in number rapidly to gain effector functions [21]. Effector functions include cytokine secretions (including interferon (IFN)- $\gamma$ and TNF- $\alpha$ ) and the ability to lyse cells [21].

$\gamma \delta \mathrm{T}$ cells are the prototype of 'unconventional' $\mathrm{T}$ cells. They make up a relatively minute subset of $\mathrm{T}$ cells in the peripheral blood. Unlike the more common CD4+ helper and CD8+ cytotoxic $\mathrm{T}$ cell populations containing a $\mathrm{T}$ cell receptor composed of classic $\alpha$ and $\beta$ chains, these cells possess a receptor composed of $\gamma$ and $\delta$ chains. They are the most abundant epithelial lymphocytes in the lung (8-20\%) and intestine where they promote immune homeostasis [22]. In the lung, they are known to protect against 


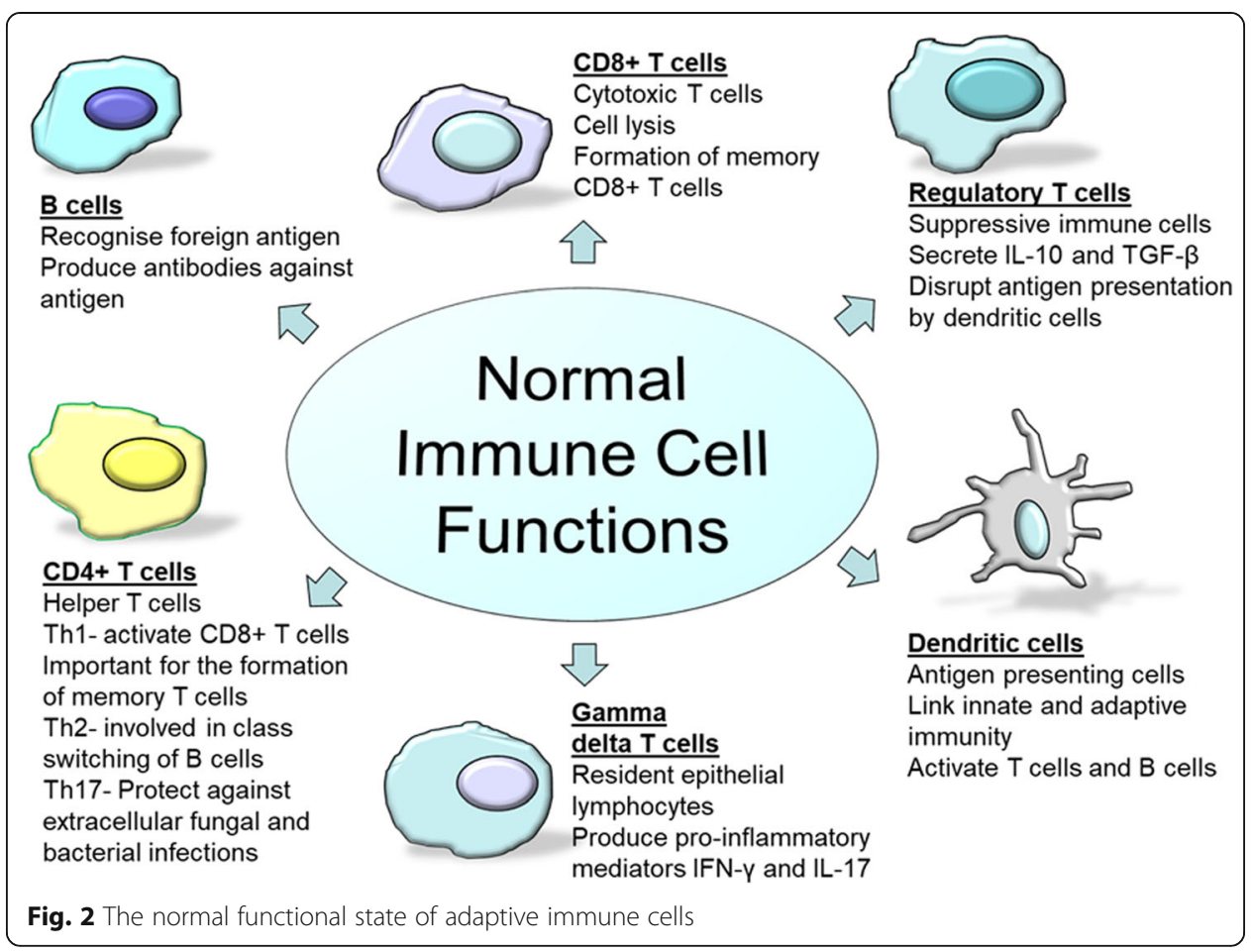

pneumonia infections [22], and they are considered the initial line of defence in the mucosa of the intestine [23]. Once activated, $\gamma \delta$ T cells release pro-inflammatory mediators including IFN- $\gamma$ and IL-17 which aid against infection.

Tregs are another important subset of $\mathrm{T}$ cells that generally represent $5-10 \%$ of total $\mathrm{CD} 4+\mathrm{T}$ cell populations in the peripheral circulation and lymphoid compartments [24]. These cells play a pivotal role in immune homeostasis by not only resolving inflammation after infection but also suppressing excessive adaptive immune responses [25]. They also work in order to maintain self-tolerance and avoid autoimmune disease [25]. They function through the secretion of suppressive cytokines including IL-10 and TGF- $\beta$, but also through cytolysis, metabolic disruption and through targeting antigen presentation by DCs [25].

It has become clear in recent years that the dichotomy between innate and adaptive immunity may indeed be an over-simplification, as some cell types are now known to display functions relating to both arms of immunity. This is particularly true for DCs which play an important role in linking innate and adaptive immunity through the process of antigen presentation [26]. They are responsible for maintaining immunological tolerance by migrating to draining lymph nodes and presenting self-antigens to lymphocytes [27]. The presence of mature DCs is also crucial as they promote the migratory potential, cytokine secretion and activation of $\mathrm{T}$ cells and can initiate antigenspecific antibody responses in naïve B cells [28].

\section{Adaptive immune response dysfunction in sepsis}

The adaptive immune response as previously mentioned has a number of roles. It is important for limiting inflammation and tissue damage after an infection and returning overall host immune homeostasis through a number of mechanisms. In sepsis, these processes and functions are disrupted or become dysregulated leading 
to an improper defence against infection and/or immune suppression; these are discussed below (Fig. 3).

\section{Cell death}

Apoptosis is an important mechanism of regulating immune homeostasis. It can also play a detrimental role in disease pathology. Apoptosis has been shown to be responsible for causing major depletion of immune cells, including CD4+ and CD8+ T cells, B cells and DCs in multiple organs from patients who died from sepsis [29-31]. This process of cell death has been observed to occur in both preclinical models and in human septic patients [32,33]. This depletion of cells has been shown to occur across all age groups and in response to different classes of microorganisms causing infection $[29,34,35]$. Post-mortem analyses have demonstrated this elevation of apoptosis in the spleens of sepsis patients 90 min post-death compared to non-septic controls [29]. Immunohistochemistry analysis in these samples has also confirmed significantly higher levels of caspase 3 activity which is indicative of the apoptotic process [29].

Other studies have shown that both CD4+ and CD8+ T cells in the peripheral blood are also more prone to undergo apoptosis in septic patients when compared to non-septic controls [36]. T cells when isolated from septic patients have increased levels of caspase 8 and caspase 9 , indicating that the death process occurs by both the intrinsic and extrinsic pathway [32]. Furthermore, genes encoding pro-apoptotic proteins Bim, Bid and Bak have been observed to be overexpressed in the peripheral blood of patients with sepsis [37]. This apoptosis of $\mathrm{T}$ cells and increased expression of pro-apoptotic proteins contributes to the chronic state of immune suppression in these patients and provides an explanation for the enhanced susceptibility to secondary infections and latent viral reactivation.

\section{T cell exhaustion}

$\mathrm{T}$ cell exhaustion is a state of $\mathrm{T}$ cell dysfunction that was first described in mice that suffered from chronic viral infections and has since been indicated with septic patients

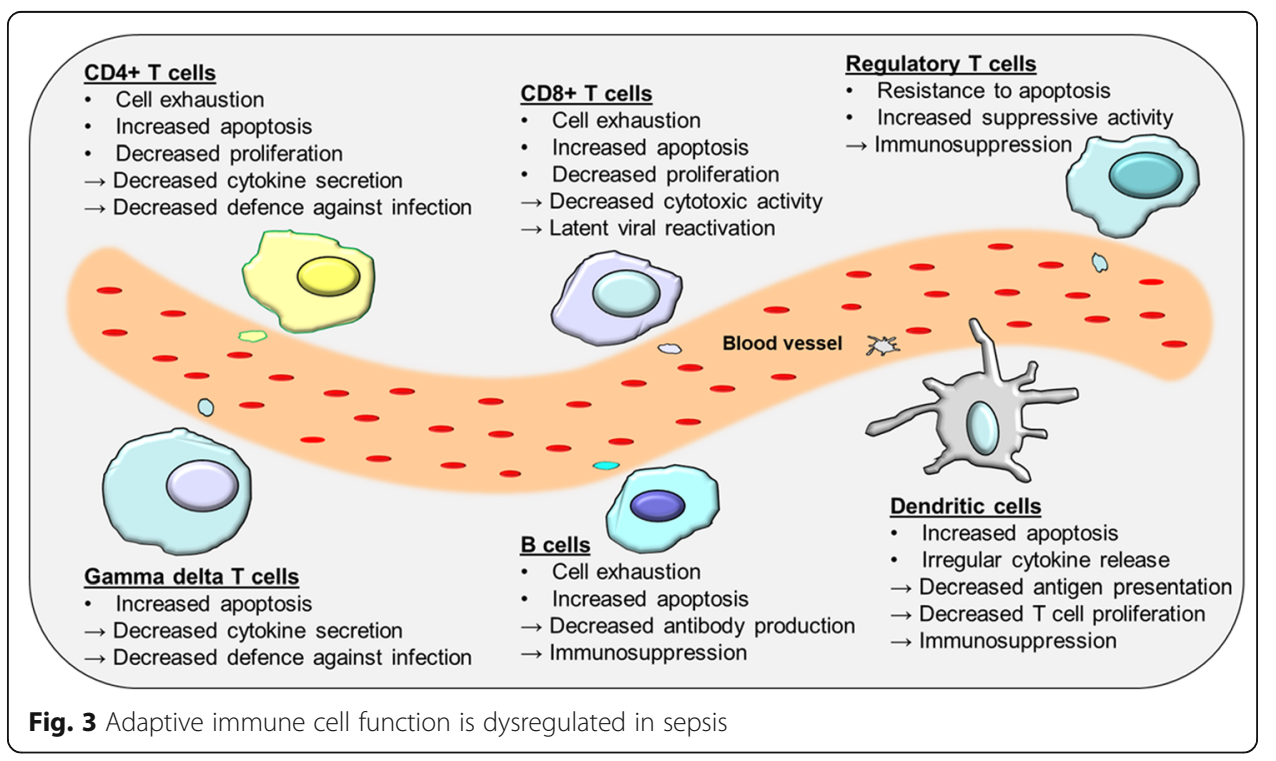


and patients with other immunocompromised diseases such as HIV and cancer [38]. In sepsis, the sustained antigen load with extremely elevated levels of both pro- and antiinflammatory cytokines constitutes an ideal environment for the development of $\mathrm{T}$ cell exhaustion [39].

One study, in which the spleens of sepsis patients were isolated following death, demonstrated substantial evidence to support the concept of sepsis-induced $\mathrm{T}$ cell exhaustion [14]. There was an evident loss of inflammatory cytokine IFN- $\gamma$ and TNF- $\alpha$ production from $\mathrm{T}$ cells following stimulation, an increase in the expression of PD1 on CD4+ T cells and a drop in the levels of CD127 on T cells which is characteristic of exhausted T cells [14]. Macrophages were also shown to possess elevated levels of programmed cell death ligand 1 (PD-L1) [14]. Other studies identified that an elevated level of PD1 on circulating T cells from individuals with sepsis is associated with a reduction of the proliferative capacity of $\mathrm{T}$ cells and an increase in the susceptibility to secondary infections, and this is correlated with mortality [40]. Inhibiting the interaction of PD1 and PDL1 in a variety of clinically relevant animal models of sepsis has been shown to improve survival rates and highlights the crucial involvement of this pathway with poor disease outcome [41-43].

\section{CD4+ T cells}

Overall, it appears that CD4+ $\mathrm{T}$ cells are the subset which are most affected in sepsis patients [32, 44, 45] (Fig. 3). CD4+ T cells undergo the most significant amount of programmed cell death, and survivors of the disease demonstrate prolonged reduction in this population of cells $[14,30]$. Studies have observed a decrease in the production IL2, IL-12 and IFN- $\gamma$ from both Th1 and Th2 populations in sepsis patients [46-48], and these cells persist in displaying significant reductions in their secretory profiles in sepsis survivors [49]. The protective effect of Th17 cells is also diminished following the onset of sepsis [50] as is their cytokine response [51]. This reduced effector capacity of Th17 cells may negatively impact outcome in sepsis by increasing the susceptibility of patients to bacterial and fungal infections [20,52].

\section{CD8+ T cells}

Studies have highlighted that the reactivation of latent viruses is known to be associated with immunocompromised individuals with sepsis [53, 54]. In a study looking at the activity of $\mathrm{T}$ cells in severe sepsis patients with human cytomegalovirus (HCMV), it was observed that there was impaired poly-functionality of CD8+ T cells [54]. Furthermore, the relative frequency of $\mathrm{CD} 8+\mathrm{T}$ cells was significantly reduced in patients who had HCMV reactivation [54]. These patients also showed enhanced PD1 expression on their $\mathrm{T}$ cells compared to patients without the virus reactivation [54], which is another example of $\mathrm{T}$ cell exhaustion. The expression of PD1 was inversely proportional to the number of poly-functional CD8+ T cells [54].

\section{$\gamma \delta$ T cells}

Depletion of $\gamma \delta$ T cells is associated with higher mortality rates in critically ill sepsis patients [23]. As mentioned previously, these cells are required for protection against infections in the lung [22]. The reduction of this cell population within the gut mucosal 
layer may also in fact result in previously non-threatening bacteria in the mucosa becoming more invasive and entering the blood system to then cause further infections in sepsis patients [55]. Along with reduction in cell number, there has been an observed phenotypic change and impaired function of $\gamma \delta$ T cells in patients with sepsis [56]. Liao et al. noted that in comparison with control patients, $\gamma \delta \mathrm{T}$ cells in septic patients had increased expression of the early activation marker CD69, decreased expression of the recognition receptor NKG2D and increases in both pro-inflammatory and antiinflammatory mediators [56]. Interestingly, they noted that following antigen stimulation, there was a significant decrease in CD69 and IFN- $\gamma$ expression [56]. This profile was more evident in non-survivors than in survivors and led the authors to conclude that lower expression of IFN- $\gamma$ expression upon stimulation is a strong indicator in patient 28-day survival rates [56].

\section{Tregs}

In sepsis, Tregs can potentiate immune suppression by further reducing other effector $\mathrm{T}$ cell numbers and functions. Unlike other effector $\mathrm{T}$ cells which are more likely to undergo apoptosis [57], Tregs have increased expression of the anti-apoptotic protein Bcl-2 [58] and can evade cell death (Fig. 3). The increase in Treg number and function has been demonstrated in both clinical $[59,60]$ and experimental studies [61, 62]. This increase has been observed early after the onset of sepsis and is persistent in those who died as a result [63]. Furthermore, there is an increase in heat shock proteins and histones in sepsis which are known to be strong inducers of Tregs [64]. The increased proportion of Tregs in sepsis has a negative effect on normal $\mathrm{T}$ cell proliferation and function and contributes to worse outcome [58], most likely because they can prevent the already weakened immune system from mounting an appropriate immune response against secondary infections.

The development and function of Tregs is regulated by FOXP3, considered to be the control gene of these cells. Along with evidence to support increased levels of Tregs in sepsis patients, there is also evidence to support that expression levels of FOXP3 is enhanced in these patients [65]. In a CLP model of sepsis, it was shown that adenosine is largely responsible for the high expression of FOXP3 [66]. TLR4 has also been implicated to affect the activity of Tregs [67]. Cao et al. showed that Tregs from wild-type mice exhibited enhanced secretion of anti-inflammatory cytokines, whereas this effect was attenuated in TLR4 ${ }^{-1-}$ mice [67]. The results from this study indicate that TLR4 deficiency can improve immune paralysis by attenuating Treg activity and by restoring a pro-inflammatory cytokine balance. Modulating the activity of TLR4 may be a useful tool in preventing immune suppression in sepsis patients. However, it is important to highlight that although Tregs can contribute to immune suppression in sepsis, Treg depletion does not improve mortality rates. In fact, one study observed the mice deficient in Tregs could not fight the initial sepsis infection [68]. Hence, it is clear that a delicate balance of Tregs is required to maintain immune homeostasis in sepsis.

\section{B cells}

B cells play a pivotal role in combating bacterial infections, but B cell dysfunction is very evident in sepsis [69]. In one study, the percentage of exhausted CD21+ B cells 
was significantly higher in patients with acute sepsis in comparison to healthy donors [70]. IgM in the serum of patients over the age of 65 was also negatively correlated with health outcomes [70]. Conversely, stimulating B cells from septic patient's ex vivo resulted in significant reduction of IgM levels in the supernatant [70]. This is an interesting finding as elderly patients with decreased IgM production are likely to be more prone to infection with gram-negative bacteria and fungi [70]. The likelihood of contracting secondary infections associated with sepsis patients has been linked to reduced immunocompetent B cells [70].

Other reports have observed further alterations in B cells derived from patients with septic shock versus age-matched healthy controls [71]. In an ICU study, a low percentage of CD23+, the receptor for IgE, and a higher percentage of CD80+ and CD95+ (indicative of apoptosis) on the surface of B cells was associated with higher levels of mortality in patients with sepsis [71]. A study by Shankar et al. showed that lymphopenia was associated with significantly lower absolute B cell counts and a selective depletion of memory B cells [72]. This depletion of memory B cells contributes to the suppressed immune state experienced by septic patients [72]. Finding methods to reverse this depletion may be beneficial in improving survival outcome for these patients.

\section{Dendritic cells}

Impairment in normal DC function appears to occur in sepsis patients and may be implicated in sepsis-associated immune suppression. The number of DCs is indeed reduced in patients with sepsis; however, the differentiation of monocytes into DCs is accelerated [31, 73], and it has been demonstrated that IL-10-treated DCs are able to suppress the activation of $\mathrm{T}$ cells and cause $\mathrm{T}$ cell anergy [74]. DCs derived from sepsis patients display an irregular secretory profile that further facilitates the development of immune tolerance [75]. DCs from septic patients have been shown to have a decreased productive capacity of pro-inflammatory cytokines and intracellular cytokine staining following LPS stimulation [76] while IL-10 secretions were shown to be enhanced [76]. Additionally, HLA-DR expression was reduced on all monocyte and DC subsets indicative of immune paralysis, and this observation was long-lasting [76]. Finally, apoptosis of DCs like other cells types has been seen in both human and in animal models of sepsis $[77,78]$. Recently, it was shown that overexpression of BCL-2 could prevent depletion of DCs [79], and preventing DC death in mice was shown to offer resistance to endotoxin-induced sepsis [80].

\section{Long-term immune suppression in sepsis patients}

Though it is understood that sepsis survivors are burdened with increased mortality and morbidity several years after developing sepsis, the precise role of sepsis-induced immune suppression in mediating these poor outcomes is not well understood. An animal study investigating the quantitative and qualitative recovery of $\mathrm{T}$ cells 3.5 months after sepsis found that despite a rapid recovery of T-lymphocytes, long-lasting impairments in the CD4+ T cells were prominent [81]. Specifically, impairment of Th cell responses against a fungal antigen was noted 1 month after sepsis, and this was thought to be directly due to the reduced number of antigen-specific Th cells [81]. 
Another 5-10-month follow-up study in sepsis patients showed an increased frequency of circulating FOXP3+ T cells, along with higher concentrations of IL-33 and IL-10 in their serum when compared to healthy controls [82]. It has been observed that mice deficient in the receptor for IL-33 show improved survival post sepsis compared to naïve wild-type mice [82]. IL-33 release is involved in the polarisation of antiinflammatory M2 macrophages that significantly release IL-10 that in turn aids in the expansion of Tregs and ultimately contributes to the immune suppressed phase of sepsis [82]. Targeting IL-33 could be another potential mechanism to treat sepsis-induced immune suppression.

\section{Preclinical studies of interventions to reverse immune deficits in sepsis}

Multiple laboratory strategies targeting different aspects of adaptive immunity have demonstrated therapeutic potential in overcoming immunosuppression in preclinical sepsis models (Table 1). Strategies including the use of transgenic and knockout mice along with the use of anti-apoptotic agents have demonstrated that by preventing lymphocyte apoptosis, there is an improvement in survival rates [83, 86, 90, 91]. Transgenic mice with $\mathrm{T}$ cell overexpression of $\mathrm{Bcl}-2$, a potent anti-apoptotic protein, were protected against sepsis-induced $\mathrm{T}$ cell apoptosis in the thymus and spleen and had greater levels of systemic inflammatory cytokines and higher survival [83]. Another study examining selective inhibition of caspase-3 prevented lymphocyte apoptosis and improved overall survival of septic mice [84]. Polycaspase inhibition produced similar results highlighting the importance of caspase-3 activity [84].

Another mechanism to prevent lymphocyte apoptosis in preclinical models of sepsis that produced exciting results was the inhibition of PD-L1 [43]. PD-1 is a co-inhibitory receptor that can be expressed primarily on activated CD4+ and CD8+ T cells. Its ligand, PD-L1, is expressed broadly on immune cells. Together, this pathway plays an important role in the regulation of autoimmunity. It has been found that expression of PD-1 is upregulated on T cells, B cells and monocytes following sepsis and that blocking this pathway using an anti-PD-L1 antibody significantly improved survival in CLP mice [43]. Additionally, sepsis-induced lymphocyte depletion was ameliorated, levels of circulating pro-inflammatory cytokines TNF- $\alpha$ and IL-6 were increased, antiinflammatory IL-10 levels were decreased and bacterial clearance was enhanced [43]. Similar studies investigating PD-1 deficiency [41] or anti-PD-1 antibodies [42] also demonstrated survival benefits in murine models of the syndrome. Another antibody approach involved the blockade of cytotoxic T-lymphocyte antigen-4 (CTLA-4) in a similar concept to blocking the PD-1-PD-L1 pathway [85]. CTLA-4 acts to oppose CD28 which is a critical regulator of early $\mathrm{T}$ cell activation and proliferation, and CTLA-4 is found to be upregulated on CD4+, CD8+ and Tregs following sepsis [85]. Here, an anti-CTLA4 antibody showed no effect on inflammatory cytokines but animal survival was increased with low doses [85].

Certain cytokines have also been trialled in these animal models to reverse sepsisinduced immunosuppression and lymphocyte apoptosis. One group reported positive results by selectively targeting thymocyte apoptosis using an adenovirus overexpressing IL-10 [86]. This was found to reduce blood bacteraemia and improve survival due to an increase in Bcl-2 expression and reduction in caspase-3 activity [86]. Of note, systemic administration had no effect on survival. Another study investigating recombinant 


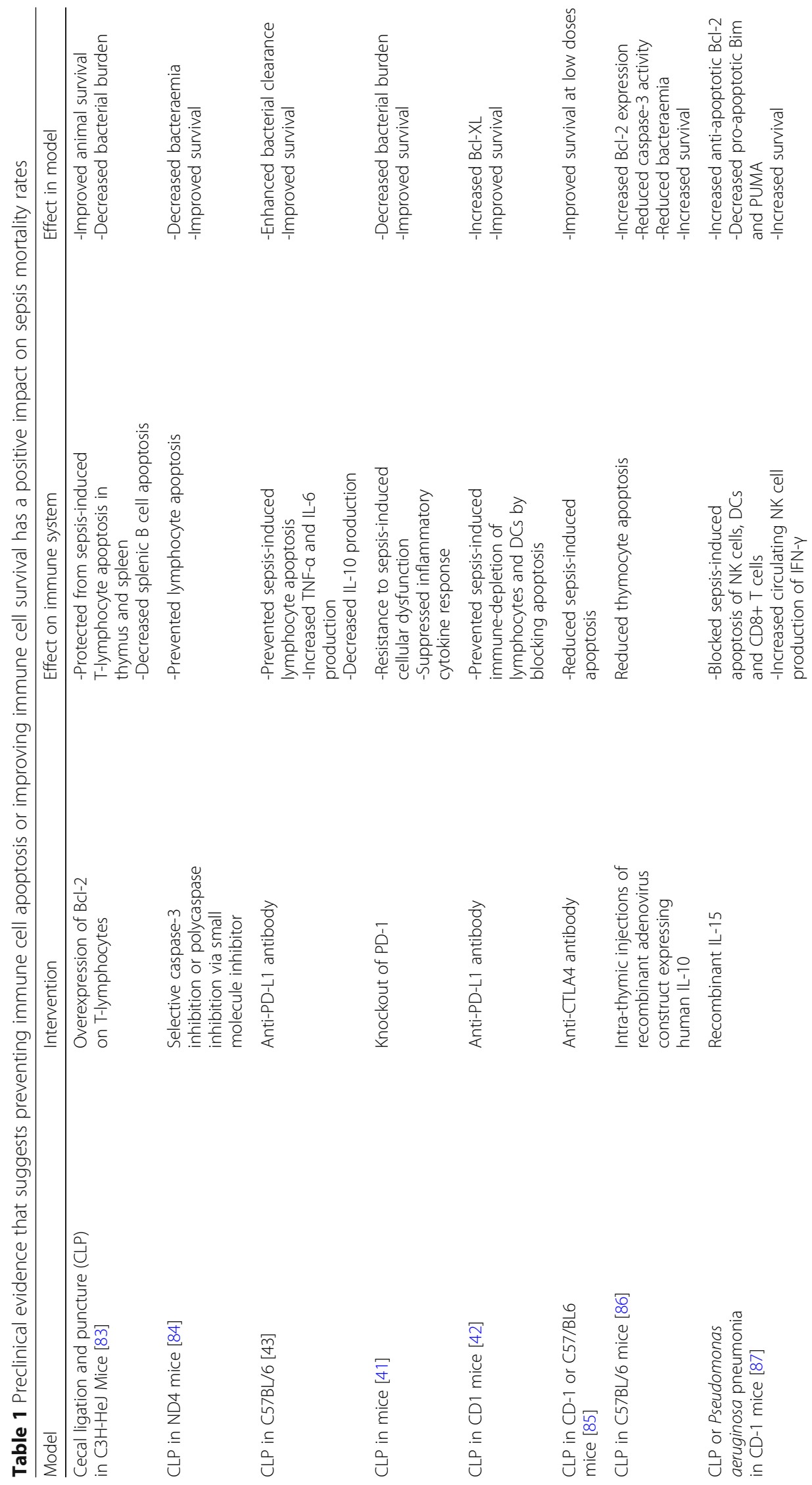




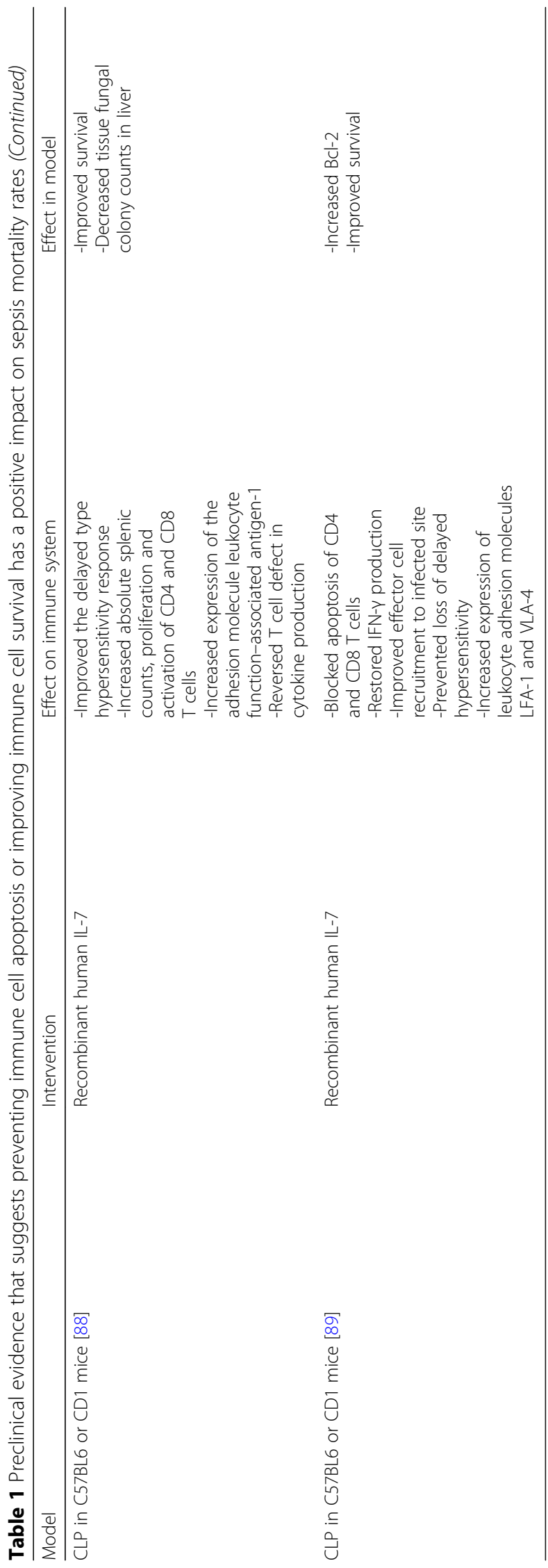


mouse IL-15 (a pluripotent cytokine that signals cells of both the innate and adaptive immune systems) showed that it inhibited the apoptosis of NK cells, DCs and CD8+ T cells and improved survival in two different models of sepsis [87]. IL-7 has also been investigated due to its potent Bcl-2-inducing anti-apoptotic abilities necessary for lymphocyte survival and expansion. In these studies, it was found that IL-7 treatment protected against lymphocyte apoptosis, restored $\mathrm{T}$ cell function and improved survival in animal models of sepsis [88, 89].

\section{Clinical studies targeting the adaptive immune response}

Early phase clinical studies using monoclonal antibodies (mAbs), recombinant interleukins and IFN therapies, aimed at targeting adaptive immune responses, have potential for sepsis therapy (Fig. 4). mAbs targeting the PD1-PD-L1 pathway have already been licenced for therapeutic use in cancer and have shown their effectiveness in reducing tumour burden [92]. As mentioned previously, this pathway is also upregulated in sepsis and sepsis does indeed immunologically bear many similarities to cancer [93] and as such this pathway could be targeted to improve outcome. Additionally, blocking this pathway in preclinical sepsis studies $[42,43,94]$ as well as ex vivo human sepsis studies [94] has built a solid case for clinical investigation.

A recently completed phase $1 \mathrm{~b}$ trial looking at immune checkpoint inhibition in patients with sepsis, organ dysfunction and absolute lymphocyte counts (ALCs) $\leq 1100$ cells $/ \mu$ l has demonstrated promising results [95]. BMS-936559, an anti-PD-L1 human immunoglobulin G4 mAb which has already been used in patients with HIV [96] and cancer [97], was given to adults with sepsis-associated immunosuppression. The primary objective was to assess safety and tolerability over 90 days following a single-dose administration. BMS-936559 was well tolerated, and there was no observed induction of any 'cytokine storms' which is a theoretical risk of any agent that inhibits immune checkpoint pathways [95]. Biological efficacy was also examined, and the investigators found that monocyte deactivation was reduced at the highest doses of treatment, as demonstrated by an increase in monocyte human leukocyte antigen-DR (HLA-DR) expression which was shown to persist past 28 days [95].

The IRIS-7 randomised clinical trial by the same group adopted a different approach to restore immune function [98]. This trial used a recombinant human IL-7 (CYT107) in septic patients in hopes of reversing the profound lymphopenia that is commonly

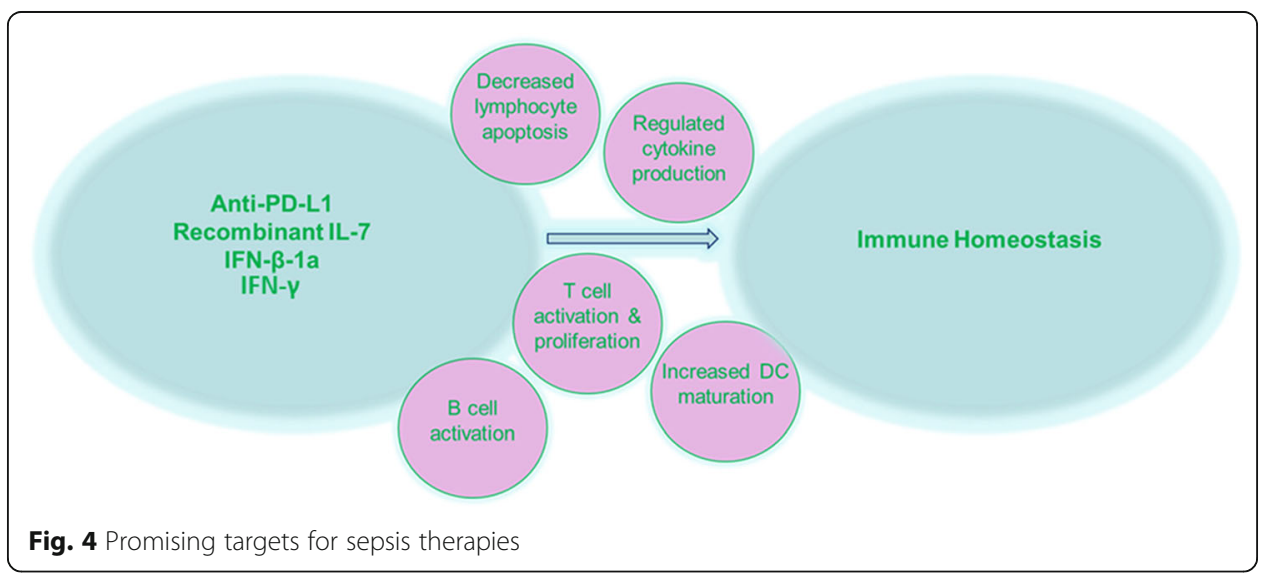


observed [99]. IL-7 treatments have previously been shown to be safe and effective at boosting $\mathrm{CD} 4+$ and $\mathrm{CD} 8+\mathrm{T}$ cell counts in oncologic and lymphopenic patients [100-102]. In this trial, it was shown that IL-7 treatment was well tolerated in septic patients and increased absolute lymphocyte counts (by 3 to 4 fold) and CD4+ and CD8+ T cells, and persistently so, 4 weeks after administration [98]. This data along with the multiple preclinical studies that have demonstrated improved survival following IL-7 administration in septic rats is highly encouraging and calls for next phase clinical testing.

Interferon therapy may be promising for sepsis. In the presence of IFN- $\beta-1 \mathrm{a}$, a type I interferon, DC maturation is enhanced which leads to the activation of $\mathrm{T}$ and B cell responses, and at the same time, DCs can limit inflammatory cytokine secretion from CD4+ $\mathrm{T}$ cells thus ensuring a state of immune homeostasis [103, 104]. A phase I/II open-label study to examine the effects of IFN- $\beta$ - 1 a in acute respiratory distress syndrome (ARDS) patients showed enhanced 28-day survival [105], but unfortunately, the recently completed phase III stage of this IFN- $\beta-1$ a study showed no clinical benefit [106]. Similar to the early phase of sepsis, ARDS is characterised by hyper-inflammation, and these two syndromes are closely connected in certain clinical scenarios [107]. As such, it would be of interest to investigate whether IFN- $\beta$ - $1 \mathrm{a}$ has therapeutic potential instead, for sepsis patients, considering reduced IFNs are implicated in the pathogenesis of the syndrome, particularly in the late immunosuppressed phase.

IFN- $\gamma$, which is a type II interferon and cytokine that aids in fighting infection, is lowered in sepsis patients. IFN- $\gamma$ was recently used as an adjunctive therapy and observed to improve clinical outcome and restore immune responses in a case series of $18 \mathrm{im}$ munosuppressed sepsis patients [108]. The sepsis patients were selected based on the fulfilment of a number of criteria indicative of immune suppression, namely the number of days following the onset of sepsis, monocytic HLA-DR expression, lymphocyte profiles, IL-6 and IL-10 levels, bacterial cultures and clinical scores [108]. Further, larger studies are warranted to verify the therapeutic potential of IFN- $\gamma$ therapy in immunosuppressed sepsis patients.

\section{Future directions: challenges and opportunities}

Recent research advances have highlighted that sepsis-induced immune suppression contributes to the high mortality rates observed in sepsis patients. Key defects in the adaptive immune response are seen as sepsis progresses, including apoptosis and dysfunction (e.g. reduced cytokine production) of key $\mathrm{T}$ cell subsets. This 'exhaustion' of $\mathrm{T}$ cells also allows invading pathogens to survive and replicate which can lead to an increasing susceptibility of patients to the contraction of secondary infections.

\section{Ageing and the adaptive immune response}

Immunosenescence refers to the gradual deterioration of the immune system with advancing age and is true for both arms of immunity but in particular for the adaptive immune response [109]. In older people, there is a shift towards memory over naïve $\mathrm{T}$ cell populations [109]. Memory $\mathrm{T}$ cells are functionally different to naïve $\mathrm{T}$ cells and 
have a limited proliferative capacity, express fewer co-stimulatory molecules and have an altered cytokine profile [110]. B cells are also altered in the elderly and despite B cell number decreasing with age, immunoglobulin levels rise [109, 111]. These immunoglobulins are derived from B1 cells rather than B2 cells and have a low affinity for antigens [111]. B1 cells are also associated with increases in IL-6 [111]. Finally, DCs are implicated in age-related adaptive immune dysfunction as they limit the secretion of IFNs, generate an irregular immune response towards self-antigens and lose their ability to activate $\mathrm{T}$ cell responses [112]. As more than half of the patients admitted to the ICU are over the age of 65 , immune-senescence poses a huge challenge for treating those older patients with sepsis [113].

\section{Sepsis heterogeneity}

Sepsis heterogeneity remains one of the biggest barriers to finding an effective therapy. Transcriptome analysis of leukocytes in the peripheral blood of sepsis patients has identified 2 phenotypes in sepsis patients, assigned as sepsis response signatures (SRS)1 or SRS2 [114]. Patients with the SRS1 phenotype were immunosuppressed with indications of $\mathrm{T}$ cell exhaustion and low leukocyte HLA-DR expression, had low immune tolerance and also exhibited higher, early mortality than the SRS2 phenotype [114]. The study identified seven genes that were able to predict the classification of patients as SRS1 or SRS2 [114]. Other biomarkers that can indicate the immune state in sepsis patients include apoptosis markers (Bim, Bid and Bac), caspases, leukocyte markers (HLA-DR, PD-1, FOXP3, CD127) and cytokines (IL-2, IL-6, IL-12, IL-17, IL-22, IL-33, TNF- $\alpha$, IFN- $\gamma$, IL-10 and TGF- $\beta$ ). Identifying subsets of sepsis patients most likely benefit from targeted and novel immunotherapies could be key to discovering effective therapies for this syndrome.

\section{Pathogen identification via host response}

Pathogen identification in sepsis patients may also help predict the ensuing sepsis response and provide a better course for management with supportive care. Hyper-inflammation and/or immune suppression can occur in sepsis regardless of the source of pathogen, i.e. whether it is bacterial, fungal or viral, and regardless of the site of infection [107, 115]. Bacterial and fungal sepsis generally results in the activation of pathogen recognition receptors (PRRs) by pathogen-associated molecular patterns (PAMPs). Intracellular signalling proceeds to initiate proinflammatory cytokine production and additional inflammatory cell recruitment $[20,115,116]$. Interestingly, studies have shown that cytokine profiles can differ and are dependent on whether the source of infection is caused by Gram-positive or Gram-negative bacteria [117]. In relation to viral insults, the host immune response is initiated by the activation of Type I, $\alpha / \beta$ IFNs and IFN- $\gamma$, which then initiate pro-inflammatory cytokine and chemokine signalling $[118,119]$. A number of viruses however can downregulate the activation of IFNs and initiate sepsis in a similar manner to non-viral pathogens [120], such as the influenza virus for example, which leads to an inflammatory state through the upregulation of cytokines [120]. 


\title{
Conclusion
}

From the initial failed studies of strategies to suppress an assumed 'overactive' sepsis immune response, to findings of lymphocyte depletion and exhaustion even in earlier phase sepsis, it is now clear that in order to successfully improve sepsis outcome and improve long-term survival rates, immune homeostasis needs to be regenerated. In light of our growing understanding of the pathogenesis of sepsis, relatively new therapies that involve immunomodulating strategies (e.g. mesenchymal stem cells [121]) are showing great potential in early phase studies and may be promising contenders for treatment of this devastating syndrome if later phase trials prove successful.

\begin{abstract}
Abbreviations
ALCs: Absolute lymphocyte countsARDSAcute respiratory distress syndromeDCsDendritic cellsyðgamma deltaHCMVHuman cytomegalovirusICUIntensive care unitsIFNInterferonILInterleukinmAbsMonoclonal antibodiesNKNatural killer cellsPD-L1Programmed cell death ligand 1ThT helperTNFTumour necrosis factorTregsRegulatory $T$ cellsSRSSepsis response signatures
\end{abstract}

Acknowledgements

Not applicable

\section{About this supplement}

This article has been published as part of Intensive Care Medicine Experimental Volume 8 Supplement 1, 2020 : Proceedings from the Fourth International Symposium on Acute Pulmonary Injury and Translation Research (INSPIRES IV). The full contents of the supplement are available at https://icm-experimental.springeropen.com/articles/ supplements/volume-8-supplement-1.

\section{Authors' contributions}

JB and SH created the first draft of the manuscript. JGL conceived of the manuscript and performed revisions. All authors revised the manuscript and approved the final version.

\section{Funding}

JB, SH and JGL are funded by an SFI Future Research Leaders grant from Science Foundation Ireland. Publication costs are funded by the INSPIRES Conference Committee.

\section{Availability of data and materials}

Not applicable

Ethics approval and consent to participate

Not applicable

\section{Consent for publication}

Not applicable

\section{Competing interests}

None

\author{
Author details \\ ${ }^{1}$ Anaesthesia, School of Medicine, Clinical Sciences Institute, National University of Ireland, Galway, Ireland. \\ ${ }^{2}$ Regenerative Medicine Institute (REMEDI) at CÚRAM Centre for Research in Medical Devices, Biomedical Sciences \\ Building, National University of Ireland Galway, Galway, Ireland. ${ }^{3}$ Department of Anaesthesia, Galway University \\ Hospitals, SAOLTA University Health Group, Galway, Ireland.
}

Received: 14 July 2020 Accepted: 16 July 2020

Published: 18 December 2020

\section{References}

1. Singer M, Deutschman CS, Seymour CW, Shankar-Hari M, Annane D, Bauer M, Bellomo R, Bernard GR, Chiche J-D, Coopersmith CM (2016) The third international consensus definitions for sepsis and septic shock (Sepsis-3). Jama 315: $801-810$

2. Vincent J-L, Marshall JC, Ñamendys-Silva SA, François B, Martin-Loeches I, Lipman J, Reinhart K, Antonelli M, Pickkers P, Njimi H (2014) Assessment of the worldwide burden of critical illness: the intensive care over nations (ICON) audit. Lancet Respir Med 2:380-386

3. Rudd KE, Johnson SC, Agesa KM, Shackelford KA, Tsoi D, Kievlan DR, Colombara DV, Ikuta KS, Kissoon N, Finfer S, Fleischmann-Struzek C, Machado FR, Reinhart KK, Rowan K, Seymour CW, Watson RS, West TE, Marinho F, Hay SI, Lozano R, Lopez AD, Angus DC, Murray CJL, Naghavi M (2020) Global, regional, and national sepsis incidence and mortality, 1990-2017: analysis for the Global Burden of Disease Study. Lancet 395:200-211

4. Torio CM, Andrews RM, (2006) National inpatient hospital costs: the most expensive conditions by payer, 2011: statistical brief\# 160 
5. Iwashyna TJ, Cooke CR, Wunsch H, Kahn JM (2012) Population burden of long-term survivorship after severe sepsis in older Americans. J Am Geriatr Soc 60:1070-1077

6. Dellinger RP, Levy MM, Rhodes A, Annane D, Gerlach H, Opal SM, Sevransky JE, Sprung CL, Douglas IS, Jaeschke R (2013) Surviving Sepsis Campaign: international guidelines for management of severe sepsis and septic shock, 2012. Intensive Care Med 39:165-228

7. Iwashyna TJ, Ely EW, Smith DM, Langa KM (2010) Long-term cognitive impairment and functional disability among survivors of severe sepsis. Jama 304:1787-1794

8. Calandra T, Cohen J (2005) The international sepsis forum consensus conference on definitions of infection in the intensive care unit. Crit Care Med 33:1538-1548

9. Hotchkiss RS, Karl IE (2003) The pathophysiology and treatment of sepsis. N Engl J Med 348:138-150

10. Tracey KJ, Fong Y, Hesse DG, Manogue KR, Lee AT, Kuo GC, Lowry SF, Cerami A (1987) Anti-cachectin/TNF monoclonal antibodies prevent septic shock during lethal bacteraemia. Nature 330:662

11. Cohen J, Opal S, Calandra T (2012) Sepsis studies need new direction. Lancet Infect Dis 12:503-505

12. Mayr FB, Yende S, Angus DC (2014) Epidemiology of severe sepsis. Virulence 5:4-11

13. Gaieski DF, Edwards JM, Kallan MJ, Carr BG (2013) Benchmarking the incidence and mortality of severe sepsis in the United States. Crit Care Med 41:1167-1174

14. Boomer JS, To K, Chang KC, Takasu O, Osborne DF, Walton AH, Bricker TL, Jarman SD, Kreisel D, Krupnick AS (2011) Immunosuppression in patients who die of sepsis and multiple organ failure. Jama 306:2594-2605

15. Hotchkiss RS, Monneret G, Payen D (2013) Sepsis-induced immunosuppression: from cellular dysfunctions to immunotherapy. Nat Rev Immunol 13:862-874

16. Winters BD, Eberlein M, Leung J, Needham DM, Pronovost PJ, Sevransky JE (2010) Long-term mortality and quality of life in sepsis: a systematic review. Crit Care Med 38:1276-1283

17. Green AM, DiFazio R, Flynn JL (2013) IFN-y from CD4 T cells is essential for host survival and enhances CD8 T cell function during Mycobacterium tuberculosis infection. J Immunol 190:270-277

18. Janssen EM, Droin NM, Lemmens EE, Pinkoski MJ, Bensinger SJ, Ehst BD, Griffith TS, Green DR, Schoenberger SP (2005) CD4+ T-cell help controls CD8+ T-cell memory via TRAll-mediated activation-induced cell death. Nature 434:88

19. Zhu J, Yamane H, Paul WE (2009) Differentiation of effector CD4 T cell populations. Annu Rev Immunol 28:445-489

20. Basu R, Hatton RD, Weaver CT (2013) The Th17 family: flexibility follows function. Immunol Rev 252:89-103

21. Kaech SM, Hemby S, Kersh E, Ahmed R (2002) Molecular and functional profiling of memory CD8 T cell differentiation. Cell 111:837-851

22. Cheng M, Hu S (2017) Lung-resident $\gamma \delta T$ cells and their roles in lung diseases. Immunology 151:375-384

23. Andreu-Ballester JC, Tormo-Calandín C, Garcia-Ballesteros C, Pérez-Griera J, Amigó V, Almela-Quilis A, del Castillo JR, Peñarroja-Otero C, Ballester F (2013) Association of $\gamma \delta$ T cells with disease severity and mortality in septic patients. Clin Vaccine Immunol 20:738-746

24. Cao C, Ma T, Y-f C, S-t S (2015) The role of regulatory T cells in immune dysfunction during sepsis. World J Emerg Med 6:5

25. Vignali DA, Collison LW, Workman CJ (2008) How regulatory T cells work. Nat Rev Immunol 8:523

26. Niessen F, Schaffner F, Furlan-Freguia C, Pawlinski R, Bhattacharjee G, Chun J, Derian CK, Andrade-Gordon P, Rosen H, Ruf W (2008) Dendritic cell PAR1-S1P3 signalling couples coagulation and inflammation. Nature 452:654

27. CR e S (2006) Dendritic cells in a mature age. Nat Rev Immunol 6:476

28. Banchereau J, Briere F, Caux C, Davoust J, Lebecque S, Liu Y-J, Pulendran B, Palucka K (2000) Immunobiology of dendritic cells. Annu Rev Immunol 18:767-811

29. Hotchkiss RS, Swanson PE, Freeman BD, Tinsley KW, Cobb JP, Matuschak GM, Buchman TG, Karl IE (1999) Apoptotic cell death in patients with sepsis, shock, and multiple organ dysfunction. Crit Care Med 27:1230-1251

30. Hotchkiss RS, Tinsley KW, Swanson PE, Schmieg RE, Hui JJ, Chang KC, Osborne DF, Freeman BD, Cobb JP, Buchman TG (2001) Sepsis-induced apoptosis causes progressive profound depletion of B and CD4+ T lymphocytes in humans. J Immunol 166:6952-6963

31. Hotchkiss RS, Tinsley KW, Swanson PE, Grayson MH, Osborne DF, Wagner TH, Cobb JP, Coopersmith C, Karl IE (2002) Depletion of dendritic cells, but not macrophages, in patients with sepsis. J Immunol 168:2493-2500

32. Hotchkiss RS, Osmon SB, Chang KC, Wagner TH, Coopersmith CM, Karl IE (2005) Accelerated lymphocyte death in sepsis occurs by both the death receptor and mitochondrial pathways. J Immunol 174:5110-5118

33. Hotchkiss RS, Swanson PE, Cobb JP, Jacobson A, Buchman TG, Karl IE (1997) Apoptosis in lymphoid and parenchymal cells during sepsis: findings in normal and T- and B-cell-deficient mice. Crit Care Med 25:1298-1307

34. Felmet KA, Hall MW, Clark RSB, Jaffe R, Carcillo JA (2005) Prolonged lymphopenia, lymphoid depletion, and hypoprolactinemia in children with nosocomial sepsis and multiple organ failure. J Immunol 174:3765-3772

35. Toti P, De Felice C, Occhini R, Schuerfeld K, Stumpo M, Epistolato MC, Vatti R, Buonocore G (2004) Spleen depletion in neonatal sepsis and chorioamnionitis. Am J Clin Pathol 122:765-771

36. Le Tulzo Y, Pangault C, Gacouin A, Guilloux V, Tribut O, Amiot L, Tattevin P, Thomas R, Fauchet R, Drénou B (2002) Early circulating lymphocyte apoptosis in human septic shock is associated with poor outcome. Shock 18:487-494

37. Weber SU, Schewe J-C, Lehmann LE, Müller S, Book M, Klaschik S, Hoeft A, Stüber F (2008) Induction of Bim and Bid gene expression during accelerated apoptosis in severe sepsis. Crit Care 12:R128

38. Zajac AJ, Blattman JN, Murali-Krishna K, Sourdive DJ, Suresh M, Altman JD, Ahmed R (1998) Viral immune evasion due to persistence of activated T cells without effector function. J Exp Med 188:2205-2213

39. Wherry EJ (2011) T cell exhaustion. Nat Immunol 12:492

40. Guignant C, Lepape A, Huang X, Kherouf H, Denis L, Poitevin F, Malcus C, Chéron A, Allaouchiche B, Gueyffier F (2011) Programmed death-1 levels correlate with increased mortality, nosocomial infection and immune dysfunctions in septic shock patients. Crit Care 15:R99

41. Huang X, Venet F, Wang YL, Lepape A, Yuan Z, Chen Y, Swan R, Kherouf H, Monneret G, Chung C-S (2009) PD-1 expression by macrophages plays a pathologic role in altering microbial clearance and the innate inflammatory response to sepsis. Proc Natl Acad Sci 106:6303-6308

42. Brahmamdam P, Inoue S, Unsinger J, Chang KC, McDunn JE, Hotchkiss RS (2010) Delayed administration of anti-PD-1 antibody reverses immune dysfunction and improves survival during sepsis. J Leukoc Biol 88:233-240 
43. Zhang Y, Zhou Y, Lou J, Li J, Bo L, Zhu K, Wan X, Deng X, Cai Z (2010) PD-L1 blockade improves survival in experimental sepsis by inhibiting lymphocyte apoptosis and reversing monocyte dysfunction. Crit Care 14:R220

44. Gouel-Chéron A, Venet F, Allaouchiche B, Monneret G (2012) CD4+ T-lymphocyte alterations in trauma patients. Crit Care 16:432

45. Inoue S, Suzuki-Utsunomiya K, Okada Y, Taira T, lida Y, Miura N, Tsuji T, Yamagiwa T, Morita S, Chiba T (2013) Reduction of immunocompetent T cells followed by prolonged lymphopenia in severe sepsis in the elderly. Crit Care Med 41:810819

46. Heidecke C-D, Hensler T, Weighardt H, Zantl N, Wagner H, Siewert J-R, Holzmann B (1999) Selective defects of T lymphocyte function in patients with lethal intraabdominal infection. Am J Surg 178:288-292

47. De AK, Kodys KM, Pellegrini J, Yeh B, Furse RK, Bankey P, Miller-Graziano CL (2000) Induction of global anergy rather than inhibitory Th2 lymphokines mediates posttrauma T cell immunodepression. Clin Immunol 96:52-66

48. Wick M, Kollig E, Muhr G, Köller M (2000) The potential pattern of circulating lymphocytes TH1/TH2 is not altered after multiple injuries. Arch Surg 135:1309-1314

49. O'Sullivan ST, Lederer JA, Horgan AF, Chin DH, Mannick JA, Rodrick ML (1995) Major injury leads to predominance of the Thelper-2 lymphocyte phenotype and diminished interleukin-12 production associated with decreased resistance to infection. Ann Surg 222:482

50. Venet F, Davin F, Guignant C, Larue A, Cazalis M-A, Darbon R, Allombert C, Mougin B, Malcus C, Poitevin-Later F (2010) Early assessment of leukocyte alterations at diagnosis of septic shock. Shock 34:358-363

51. Wu H-P, Chung K, Lin C-Y, Jiang B-Y, Chuang D-Y, Liu Y-C (2013) Associations of T helper 1, 2, 17 and regulatory T lymphocytes with mortality in severe sepsis. Inflamm Res 62:751-763

52. Smeekens SP, Ng A, Kumar V, Johnson MD, Plantinga TS, Van Diemen C, Arts P, Verwiel ETP, Gresnigt MS, Fransen K (2013) Functional genomics identifies type I interferon pathway as central for host defense against Candida albicans. Nat Commun 4:1342

53. Walton AH, Muenzer JT, Rasche D, Boomer JS, Sato B, Brownstein BH, Pachot A, Brooks TL, Deych E, Shannon WD (2014) Reactivation of multiple viruses in patients with sepsis. PLOS ONE 9:e98819

54. Choi YJ, Kim SB, Kim JH, Park S-H, Park MS, Kim JM, Han SH, Shin E-C (2017) Impaired polyfunctionality of CD8+ T cells in severe sepsis patients with human cytomegalovirus reactivation. Exp Mol Med 49:e382

55. Tomasello E, Bedoui S (2013) Intestinal innate immune cells in gut homeostasis and immunosurveillance. Immunol Cell Biol 91:201-203

56. Liao X-L, Feng T, Zhang J-Q, Cao X, Wu Q-H, Xie Z-C, Kang Y, Li H (2017) Phenotypic changes and impaired function of peripheral $\gamma \delta$ T cells in patients with sepsis. Shock: Injury, Inflammation, and Sepsis: Laboratory and Clinical Approaches 48:321-328

57. Venet F, Pachot A, Debard A-L, Bohé J, Bienvenu J, Lepape A, Monneret G (2004) Increased percentage of CD4+ CD25+ regulatory $T$ cells during septic shock is due to the decrease of CD4+ CD25- lymphocytes. Crit Care Med 32:2329-2331

58. Venet F, Chung C-S, Kherouf H, Geeraert A, Malcus C, Poitevin F, Bohé J, Lepape A, Ayala A, Monneret G (2009) Increased circulating regulatory T cells (CD4+ CD25+ CD127-) contribute to lymphocyte anergy in septic shock patients. Intensive Care Med 35:678

59. Tatura R, Zeschnigk M, Adamzik M, Probst-Kepper M, Buer J, Kehrmann J (2012) Quantification of regulatory T cells in septic patients by real-time PCR-based methylation assay and flow cytometry. PLoS ONE 7:e49962

60. Gupta DL, Bhoi S, Mohan T, Galwnkar S, Rao DN (2016) Coexistence of Th1/Th2 and Th17/Treg imbalances in patients with post traumatic sepsis. Cytokine 88:214-221

61. Y-y L, C-f Y, Q-h Q, Dong N, Zhu X-m, Z-y S, Q-h Z, Y-m Y (2015) Effect of regulatory T cells on promoting apoptosis of T lymphocyte and its regulatory mechanism in sepsis. J Interf Cytokine Res 35:969-980

62. Tatura R, Zeschnigk M, Hansen W, Steinmann J, Goncalves Vidigal P, Hutzler M, Pastille E, Westendorf AM, Buer J, Kehrmann J (2015) Relevance of Foxp3+ regulatory T cells for early and late phases of murine sepsis. Immunology 146: 144-156

63. Monneret G, Debard A-L, Venet F, Bohe J, Hequet O, Bienvenu J, Lepape A (2003) Marked elevation of human circulating CD4+ CD25+ regulatory T cells in sepsis-induced immunoparalysis. Crit Care Med 31:2068-2071

64. Zanin-Zhorov A, Cahalon L, Tal G, Margalit R, Lider O, Cohen IR (2018) Heat shock protein 60 enhances CD4+ CD25+ regulatory $T$ cell function via innate TLR2 signaling. J Clin Invest 128

65. Scumpia PO, Delano MJ, Kelly KM, O'Malley KA, Efron PA, McAuliffe PF, Brusko T, Ungaro R, Barker T, Wynn JL (2006) Increased natural $\mathrm{CD} 4+\mathrm{CD} 25+$ regulatory $\mathrm{T}$ cells and their suppressor activity do not contribute to mortality in murine polymicrobial sepsis. J Immunol 177:7943-7949

66. Bao R, Hou J, Li Y, Bian J, Deng X, Zhu X, Yang T (2016) Adenosine promotes Foxp3 expression in Treg cells in sepsis model by activating JNK/AP-1 pathway. Am J Transl Res 8:2284

67. Cao C, Chai Y, Shou S, Wang J, Huang Y, Ma T (2018) Toll-like receptor 4 deficiency increases resistance in sepsisinduced immune dysfunction. Int Immunopharmacol 54:169-176

68. Kuhlhorn F, Rath M, Schmoeckel K, Cziupka K, Nguyen HH, Hildebrandt P, Hunig T, Sparwasser T, Huehn J, Potschke C, Broker BM (2013) Foxp3+ regulatory T cells are required for recovery from severe sepsis. PLoS ONE 8:e65109

69. Kelly-Scumpia KM, Scumpia PO, Weinstein JS, Delano MJ, Cuenca AG, Nacionales DC, Wynn JL, Lee PY, Kumagai Y, Efron PA (2011) B cells enhance early innate immune responses during bacterial sepsis. J Exp Med 208:1673-1682

70. Suzuki K, Inoue S, Kametani Y, Komori Y, Chiba S, Sato T, Inokuchi S, Ogura S (2016) Reduced immunocompetent B cells and increased secondary infection in elderly patients with severe sepsis. Shock 46:270-278

71. Monserrat J, de Pablo R, Diaz-MartÃn D, RodrÃguez-Zapata M, de la Hera A, Prieto A, Alvarez-Mon M (2013) Early alterations of B cells in patients with septic shock. Crit Care 17:R105

72. Shankar-Hari M, Fear D, Lavender P, Mare T, Beale R, Swanson C, Singer M, Spencer J (2017) Activation-associated accelerated apoptosis of memory B cells in critically ill patients with sepsis. Crit Care Med 45:875-882

73. Faivre V, Lukaszewicz AC, Alves A, Charron D, Payen D, Haziot A (2007) Accelerated in vitro differentiation of blood monocytes into dendritic cells in human sepsis. Clin Exp Immunol 147:426-439

74. Steinbrink K, Graulich E, Kubsch S, Knop J, Enk AH (2002) CD4+ and CD8+ anergic T cells induced by interleukin-10treated human dendritic cells display antigen-specific suppressor activity. Blood 99:2468-2476 
75. Pastille E, Didovic S, Brauckmann D, Rani M, Agrawal H, Schade FU, Zhang Y, Flohé SB (2011) Modulation of dendritic cell differentiation in the bone marrow mediates sustained immunosuppression after polymicrobial sepsis. J Immunol 186:977-986

76. Poehlmann H, Schefold JC, Zuckermann-Becker H, Volk H-D, Meisel C (2009) Phenotype changes and impaired function of dendritic cell subsets in patients with sepsis: a prospective observational analysis. Crit Care 13:R119

77. Y-y L, Y-m Y, X-z X, Z-y S (2015) Insights into the apoptotic death of immune cells in sepsis. J Interf Cytokine Res 35:1722

78. Tinsley KW, Grayson MH, Swanson PE, Drewry AM, Chang KC, Karl IE, Hotchkiss RS (2003) Sepsis induces apoptosis and profound depletion of splenic interdigitating and follicular dendritic cells. J Immunol 171:909-914

79. Peck-Palmer OM, Unsinger J, Chang KC, McDonough JS, Perlman H, McDunn JE, Hotchkiss RS, (2009) Modulation of the $\mathrm{BCl}-2$ family blocks sepsis-induced depletion of dendritic cells and macrophages. Shock (Augusta, Ga) 31: 359

80. Gautier EL, Huby T, Saint-Charles F, Ouzilleau B, Chapman MJ, Lesnik P (2008) Enhanced dendritic cell survival attenuates lipopolysaccharide-induced immunosuppression and increases resistance to lethal endotoxic shock. J Immunol 180: 6941-6946

81. Ammer-Herrmenau C, Kulkarni U, Andreas N, Ungelenk M, Ravens S, Hübner C, Kather A, Kurth I, Bauer M, Kamradt T (2019) Sepsis induces long-lasting impairments in CD4+ T-cell responses despite rapid numerical recovery of Tlymphocyte populations. PLoS ONE 14:e0211716

82. Nascimento DC, Melo PH, Pineros AR, Ferreira RG, Colón DF, Donate PB, Castanheira FV, Gozzi A, Czaikoski PG, Niedbala W (2017) IL-33 contributes to sepsis-induced long-term immunosuppression by expanding the regulatory $T$ cell population. Nat Commun 8:14919

83. Hotchkiss RS, Swanson PE, Knudson CM, Chang KC, Cobb JP, Osborne DF, Zollner KM, Buchman TG, Korsmeyer SJ, Karl IE (1999) Overexpression of BCl-2 in transgenic mice decreases apoptosis and improves survival in sepsis. J Immunol $162: 4148-4156$

84. Hotchkiss R, Chang K, Swanson P, Tinsley K, Hui J, Klender P, Xanthoudakis S, Roy S, Black C, Grimm E (2000) Caspase inhibitors improve survival in sepsis: a critical role of the lymphocyte. Nat Immunol 1:496

85. Inoue S, Bo L, Bian J, Unsinger J, Chang K, Hotchkiss RS, (2011) Dose dependent effect of anti-CTLA-4 on survival in sepsis. Shock (Augusta, Ga) 36: 38

86. Oberholzer C, Oberholzer A, Bahjat FR, Minter RM, Tannahill CL, Abouhamze A, LaFace D, Hutchins B, Clare-Salzler MJ, Moldawer LL (2001) Targeted adenovirus-induced expression of IL-10 decreases thymic apoptosis and improves survival in murine sepsis. Proc Natl Acad Sci 98:11503-11508

87. Inoue S, Unsinger J, Davis CG, Muenzer JT, Ferguson TA, Chang K, Osborne DF, Clark AT, Coopersmith CM, McDunn JE (2010) IL-15 prevents apoptosis, reverses innate and adaptive immune dysfunction, and improves survival in sepsis. J Immunol 184:1401-1409

88. Unsinger J, Burnham C-AD, McDonough J, Morre M, Prakash PS, Caldwell CC, Dunne WM Jr, Hotchkiss RS (2012) Interleukin-7 ameliorates immune dysfunction and improves survival in a 2-hit model of fungal sepsis. J Infect Dis 206: 606-616

89. Unsinger J, McGlynn M, Kasten KR, Hoekzema AS, Watanabe E, Muenzer JT, McDonough JS, Tschoep J, Ferguson TA, McDunn JE (2010) IL-7 promotes T cell viability, trafficking, and functionality and improves survival in sepsis. J Immunol 184:3768-3779

90. Chung CS, Song GY, Lomas J, Simms HH, Chaudry IH, Ayala A (2003) Inhibition of Fas/Fas ligand signaling improves septic survival: differential effects on macrophage apoptotic and functional capacity. J Leukoc Biol 74:344-351

91. Iwata A, Stevenson VM, Minard A, Tasch M, Tupper J, Lagasse E, Weissman I, Harlan JM, Winn RK (2003) Over-expression of $\mathrm{BCl}-2$ provides protection in septic mice by a trans effect. J Immunol 171:3136-3141

92. Motzer RJ, Tannir NM, McDermott DF, Arén Frontera O, Melichar B, Choueiri TK, Plimack ER, Barthélémy P, Porta C, George S (2018) Nivolumab plus ipilimumab versus sunitinib in advanced renal-cell carcinoma. N Engl J Med 378:12771290

93. Venet F, Monneret G (2018) Advances in the understanding and treatment of sepsis-induced immunosuppression. Nat Rev Nephrol 14:121

94. Chang KC, Burnham C-A, Compton SM, Rasche DP, Mazuski R, SMcDonough J, Unsinger J, Korman AJ, Green JM, Hotchkiss RS (2013) Blockade ofthe negative co-stimulatory molecules PD-1 and CTLA-4 improves survival in primary and secondary fungal sepsis. Crit Care 17:R85

95. Hotchkiss RS, Colston E, Yende S, Angus DC, Moldawer LL, Crouser ED, Martin GS, Coopersmith CM, Brakenridge S, Mayr FB, (2019) Immune checkpoint inhibition in sepsis: a phase 1b randomized, placebo-controlled, single ascending dose study of antiprogrammed cell death-ligand 1 (BMS-936559). Critical care medicine

96. Gay CL, Bosch RJ, Ritz J, Hataye JM, Aga E, Tressler RL, Mason SW, Hwang CK, Grasela DM, Ray N (2017) Clinical trial of the anti-PD-L1 antibody BMS-936559 in HIV-1 infected participants on suppressive antiretroviral therapy. J Infect Dis 215: $1725-1733$

97. Brahmer JR, Tykodi SS, Chow LQ, Hwu W-J, Topalian SL, Hwu P, Drake CG, Camacho LH, Kauh J, Odunsi K (2012) Safety and activity of anti-PD-L1 antibody in patients with advanced cancer. N Engl J Med 366:2455-2465

98. Francois B, Jeannet R, Daix T, Walton AH, Shotwell MS, Unsinger J, Monneret G, Rimmelé T, Blood T, Morre M, (2018) Interleukin-7 restores lymphocytes in septic shock: the IRIS-7 randomized clinical trial. JCI insight 3

99. Drewry AM, Samra N, Skrupky LP, Fuller BM, Compton SM, Hotchkiss RS, (2014) Persistent lymphopenia after diagnosis of sepsis predicts mortality. Shock (Augusta, Ga) 42: 383

100. Perales M-A, Goldberg JD, Yuan J, Koehne G, Lechner L, Papadopoulos EB, Young JW, Jakubowski AA, Zaidi B, Gallardo H (2012) Recombinant human interleukin-7 (CYT107) promotes T-cell recovery after allogeneic stem cell transplantation. Blood 120:4882-4891

101. Levy Y, Sereti I, Tambussi G, Routy J, Lelievre J, Delfraissy J, Molina J, Fischl M, Goujard C, Rodriguez B (2012) Effects of recombinant human interleukin 7 on T-cell recovery and thymic output in HIV-infected patients receiving antiretroviral therapy: results of a phase I/lla randomized, placebo-controlled, multicenter study. Clin Infect Dis 55:291-300

102. Sereti I, Dunham RM, Spritzler J, Aga E, Proschan MA, Medvik K, Battaglia CA, Landay AL, Pahwa S, Fischl MA (2009) IL-7 administration drives T cell-cycle entry and expansion in HIV-1 infection. Blood 113:6304-6314 
103. Abediankenari S, Shaker D, Abedian F, Mirabi A (2009) The effect of beta interferon on dendritic cells and cytokine synthesis by CD4+ T cells. Iran J Immunol 6:61-66

104. Le Bon A, Tough DF (2002) Links between innate and adaptive immunity via type I interferon. Curr Opin Immunol 14: $432-436$

105. Bellingan G, Maksimow M, Howell DC, Stotz M, Beale R, Beatty M, Walsh T, Binning A, Davidson A, Kuper M, Shah S, Cooper J, Waris M, Yegutkin GG, Jalkanen J, Salmi M, Piippo I, Jalkanen M, Montgomery H, Jalkanen S (2014) The effect of intravenous interferon-beta-1a (FP-1201) on lung CD73 expression and on acute respiratory distress syndrome mortality: an open-label study. Lancet Respir Med 2:98-107

106. Ranieri VM, Pettila V, Karvonen MK, Jalkanen J, Nightingale P, Brealey D, Mancebo J, Ferrer R, Mercat A, Patroniti N, Quintel M, Vincent JL, Okkonen M, Meziani F, Bellani G, MacCallum N, Creteur J, Kluge S, Artigas-Raventos A, Maksimow M, Piippo I, Elima K, Jalkanen S, Jalkanen M, Bellingan G (2020) Effect of intravenous interferon beta-1a on death and days free from mechanical ventilation among patients with moderate to severe acute respiratory distress syndrome: a randomized clinical trial. JAMA

107. Cs C, Fn J (2019) Organ dysfunction in sepsis: an ominous trajectory from infection to death. The Yale journal of biology and medicine 92:629-640

108. Payen D, Faivre V, Miatello J, Leentjens J, Brumpt C, Tissieres P, Dupuis C, Pickkers P, Lukaszewicz AC (2019) Multicentric experience with interferon gamma therapy in sepsis induced immunosuppression. A case series. BMC Infect Dis 19:931

109. Opal SM, Girard TD, Ely EW (2005) The immunopathogenesis of sepsis in elderly patients. Clin Infect Dis 41(Suppl 7): S504-S512

110. Sandmand M, Bruunsgaard H, Kemp K, Andersen-Ranberg K, Pedersen AN, Skinhoj P, Pedersen BK (2002) Is ageing associated with a shift in the balance between type 1 and type 2 cytokines in humans? Clin Exp Immunol 127:107-114

111. Weksler ME, Goodhardt M, Szabo P (2002) The effect of age on B cell development and humoral immunity. Springer Semin Immunopathol 24:35-52

112. Agrawal A, Agrawal S, Gupta S (2017) Role of dendritic cells in inflammation and loss of tolerance in the elderly. Front Immunol 8

113. Pisani MA (2009) Considerations in caring for the critically ill older patient. J Intensive Care Med 24:83-95

114. Davenport EE, Burnham KL, Radhakrishnan J, Humburg P, Hutton P, Mills TC, Rautanen A, Gordon AC, Garrard C, Hill AVS, Hinds CJ, Knight JC (2016) Genomic landscape of the individual host response and outcomes in sepsis: a prospective cohort study. Lancet Respir Med 4:259-271

115. Wiersinga WJ, Seymour CW (2018) Handbook of Sepsis. Springer,

116. Netea MG, Joosten LA, van der Meer JW, Kullberg BJ, van de Veerdonk FL (2015) Immune defence against Candida fungal infections. Nat Rev Immunol 15:630-642

117. Surbatovic M, Popovic N, Vojvodic D, Milosevic I, Acimovic G, Stojicic M, Veljovic M, Jevdjic J, Djordjevic D, Radakovic S (2015) Cytokine profile in severe Gram-positive and Gram-negative abdominal sepsis. Sci Rep 5:11355

118. Kelly-Scumpia KM, Scumpia PO, Delano MJ, Weinstein JS, Cuenca AG, Wynn JL, Moldawer LL (2010) Type I interferon signaling in hematopoietic cells is required for survival in mouse polymicrobial sepsis by regulating CXCL10. J Exp Med 207:319-326

119. Levy DE, García-Sastre A (2001) The virus battles: IFN induction of the antiviral state and mechanisms of viral evasion. Cytokine Growth Factor Rev 12:143-156

120. Florescu DF, Kalil AC (2014) The complex link between influenza and severe sepsis. Virulence 5:137-142

121. Keane C, Jerkic M, Laffey JG (2017) stem cell-based therapies for sepsis. Anesthesiology 127:1017-1034

\section{Publisher's Note}

Springer Nature remains neutral with regard to jurisdictional claims in published maps and institutional affiliations.

\section{Submit your manuscript to a SpringerOpen ${ }^{\circ}$ journal and benefit from:}

- Convenient online submission

- Rigorous peer review

- Open access: articles freely available online

- High visibility within the field

- Retaining the copyright to your article

Submit your next manuscript at $\boldsymbol{\nabla}$ springeropen.com 